\title{
Effects of Roflumilast, a Phosphodiesterase-4 Inhibitor, on the Lung Functions in a Saline Lavage-Induced Model of Acute Lung Injury
}

\author{
P. KOSUTOVA ${ }^{1,2}$, P. MIKOLKA ${ }^{1,2}$, M. KOLOMAZNIK ${ }^{1,2}$, S. $_{\text {REZAKOVA }}{ }^{1,2}$, \\ A. CALKOVSKA ${ }^{1,2}$, D. MOKRA ${ }^{1,2}$
}

${ }^{1}$ Department of Physiology, Jessenius Faculty of Medicine in Martin, Comenius University in Bratislava, Martin, Slovakia, ${ }^{2}$ Biomedical Center Martin, Jessenius Faculty of Medicine in Martin, Comenius University in Bratislava, Martin, Slovakia

Received March 7, 2017

Accepted April 21, 2017

\begin{abstract}
Summary
Acute lung injury (ALI) is associated with deterioration of alveolar-capillary lining and transmigration and activation of inflammatory cells. Whereas a selective phosphodiesterase-4 (PDE4) inhibitor roflumilast has exerted potent anti-inflammatory properties, this study evaluated if its intravenous delivery can influence inflammation, edema formation, and respiratory parameters in rabbits with a lavage-induced model of ALI. ALI was induced by repetitive saline lung lavage $(30 \mathrm{ml} / \mathrm{kg})$. Animals were divided into 3 groups: ALI without therapy (ALI), ALI treated with roflumilast i.v. (1 mg/kg; ALI+Rofl), and healthy ventilated controls (Control), and were ventilated for following $4 \mathrm{~h}$. Respiratory parameters (blood gases, ventilatory pressures, lung compliance, oxygenation indexes etc.) were measured and calculated regularly. At the end of experiment, animals were overdosed by anesthetics. Total and differential counts of cells in bronchoalveolar lavage fluid (BAL) were estimated microscopically. Lung edema was expressed as wet/dry lung weight ratio. Treatment with roflumilast reduced leak of cells $(P<0.01)$, particularly of neutrophils $(P<0.001)$, into the lung, decreased lung edema formation $(P<0.01)$, and improved respiratory parameters. Concluding, the results indicate a future potential of PDE4 inhibitors also in the therapy of ALI.
\end{abstract}

\section{Key words}

Roflumilast $\bullet$ Lung injury $\bullet$ Inflammation $\bullet$ Lung functions $\bullet$ Lung edema

\section{Corresponding author}

D. Mokra, Biomedical Center Martin and Department of Physiology, Jessenius Faculty of Medicine in Martin, Comenius University in Bratislava, Mala Hora 4C, 03601 Martin, Slovakia. E-mail: mokra@jfmed.uniba.sk

\section{Introduction}

The acute lung injury (ALI) and acute respiratory distress syndrome (ARDS) are clinical syndromes characterized by decreased lung compliance, bilateral pulmonary infiltrates, and hypoxemia which have direct or indirect lung etiology (Ware 2006, Matthay et al. 2012). An acute exudative phase of the syndromes involves an alveolar-capillary leakage in conjunction with a leukocyte extravasation. This is followed by a fibroproliferative phase which includes hyaline membrane formation, persistent inflammation, and proliferation of alveolar epithelial cells and mesenchymal cells. In the lung inflammation, recruitment of circulating polymorphonuclears (PMN) is essential for a host defense and initiates a specific immune response; whereas a pathological hallmark of ALI/ARDS is an uncontrolled transmigration of neutrophils into the lung interstitium and alveolar space and their recruitment (Grommes and Soehnlein 2011, Matthay et al. 2012).

There is a variety of inflammatory reactions activated in ALI/ARDS, with complex interactions between the cells and mediators where some of them have not been completely elucidated yet. However, therapeutic modification of these reactions by anti-inflammatory agents can suppress the inflammatory changes and finally improve the patient's status. For instance, 3',5'-cyclic adenosine monophosphate (cAMP) is an intracellular signaling molecule which regulates a broad range of cell processes. cAMP is formed from ATP by action of enzyme adenylate cyclase. Signaling 
initiated by cAMP formation is partially terminated via degradation of the compound by phosphodiesterases (PDEs) which hydrolyse cAMP to inactive 5'-AMP (Maurice et al. 2014). From the PDEs family of eleven known classes, eight are able to hydrolyse cAMP. Among them, PDE4 is proposed to play an exceptional role in ALI as it is expressed in inflammatory and immunomodulatory cells including neutrophils and macrophages, and in the lung airway epithelial cells, endothelial cells, smooth muscle cells etc. (Houslay et al. 2005). Thanks to modulation of PDE4 in these cells, PDE4 inhibitors have become valuable therapies for chronic lung diseases such as chronic obstructive pulmonary disease (COPD) and bronchial asthma (Parikh and Chakraborti 2016). Nevertheless, there is a lack of information on potential benefit of PDE4 inhibitors in acute lung injury. Therefore, the purpose of this study was to investigate whether a selective PDE4 inhibitor roflumilast can positively influence the respiratory parameters, migration of PMN and formation of lung edema in animals with ALI induced by repetitive saline lung lavage.

\section{Methods}

\section{General design of experiments}

Experimental protocols were performed in accordance with the ethical guidelines and were authorized by the local Ethics Committee of Jessenius Faculty of Medicine and by National Veterinary Board.

In the study, young New Zealand white rabbits of both genders and a mean body weight (b.w.) of $2.5 \pm 0.3 \mathrm{~kg}$ were used. Animals were anesthetized with intramuscular tiletamine + zolazepam $(15 \mathrm{mg} / \mathrm{kg}$ b.w.; Zoletil, Virbac, France) and xylazine ( $5 \mathrm{mg} / \mathrm{kg}$ b.w.; Xylariem, Riemser, Germany), followed by an infusion of tiletamine + zolazepam $(10 \mathrm{mg} / \mathrm{kg} / \mathrm{h} \quad$ i.v. $)$. A tracheotomy was performed and an endotracheal tube was inserted. Catheters into the femoral artery and right atrium for sampling the arterial and mixed venous blood and into the femoral vein to administer anesthetics were inserted. Animals were paralyzed with pipecuronium bromide $(0.3 \mathrm{mg} / \mathrm{kg}$ b.w. $/ 30 \mathrm{~min}$; Arduan, Gedeon Richter, Hungary) and subjected to ventilator Aura V (Chirana, Slovakia) and were ventilated conventionally with following settings: frequency (f) of 40/min, fraction of inspired oxygen $\left(\mathrm{FiO}_{2}\right)$ of 1.0, time of inspiration (Ti) $50 \%$, positive end-expiratory pressure (PEEP) $0.5 \mathrm{kPa}$, and peak inspiratory pressure (PIP) to achieve a tidal volume $\left(\mathrm{V}_{\mathrm{T}}\right)<6 \mathrm{ml} / \mathrm{kg}$ b.w. After $15 \mathrm{~min}$ of stabilization, respiratory parameters were recorded and blood samples for analysis of blood gases (RapidLab 348, Siemens, Germany) were taken. One group of animals served as healthy ventilated and non-treated controls (Control group, $n=6)$. In other animals, the lung injury was induced by repetitive lung lavage with saline $(0.9 \%$ $\mathrm{NaCl}, 30 \mathrm{ml} / \mathrm{kg}$ b.w., $37^{\circ} \mathrm{C}$ ) which was instilled into the endotracheal cannula in the semi-upright right and left lateral positions of the animal and was immediately suctioned by a suction device. Lavage was performed 6-12 times, until $\mathrm{PaO}_{2}$ decreased to $<26.7 \mathrm{kPa}$ in 2 measurements at 5 and $15 \mathrm{~min}$ after the lavage. When the criteria of the ALI model were full-filled, respiratory parameters were recorded and blood samples taken again. Then, animals were treated with roflumilast $(1 \mathrm{mg} / \mathrm{kg}$ b.w.; ALI+Rofl group, $n=8$ ) which was given intravenously during $2 \mathrm{~min}$, or were left without therapy (ALI group, $\mathrm{n}=8$ ). All animals were oxygen-ventilated $\left(\mathrm{FiO}_{2} 1.0\right.$, frequency $40 / \mathrm{min}$, PEEP $0.5 \mathrm{kPa}, \mathrm{V}_{\mathrm{T}}<6 \mathrm{ml} / \mathrm{kg}$ b.w.) for an additional $4 \mathrm{~h}$ after administration of the treatment. Blood gases and respiratory parameters were measured at $0.5,1,2,3$, and $4 \mathrm{~h}$ of the treatment. At the end of experiment, animals were sacrificed by an overdose of anesthetics.

\section{Measurement of respiratory parameters}

During experiment, animals were ventilated with ventilator Aura V (Chirana, Slovakia). Ventilatory parameters, such as $\mathrm{V}_{\mathrm{T}}, \mathrm{FiO}_{2}$, minute ventilation, $\mathrm{Ti}$, f, ventilatory pressures [mean airway pressure (MAP), PIP and PEEP], static (Cst) and dynamic (Cdyn) lung compliance, and airway resistance (Raw) were automatically measured by in-build sensors and software and were displayed on the screen of the ventilator. Partial pressures of oxygen and carbon dioxide $\left(\mathrm{PaO}_{2}\right.$ and $\left.\mathrm{PaCO}_{2}\right)$, arterial $\mathrm{pH}$, arterial oxygen saturation $\left(\mathrm{SaO}_{2}\right)$, and parameters of acid-base balance were measured with blood gas analyzer (Rapidlab 348, Siemens, Germany). Ventilation efficiency index was calculated as:

$$
\mathrm{VEI}=3800 /\left[(\mathrm{PIP}-\mathrm{PEEP}) \times \text { frequency } \times \mathrm{PaCO}_{2}\right] \text {. }
$$

The oxygenation index (OI) was calculated as:

$$
\mathrm{OI}=\left[\mathrm{MAP}(\mathrm{kPa}) \times \mathrm{FiO}_{2}(\%)\right] / \mathrm{PaO}_{2}(\mathrm{kPa}) \text {. }
$$

The $\mathrm{PaO}_{2} / \mathrm{FiO}_{2}$ ratio, the $\mathrm{PF}$ for short, was calculated as:

$$
\mathrm{PF} \text { ratio }=\left[\mathrm{PaO}_{2}(\mathrm{mmHg}) \times 100\right] / \mathrm{FiO}_{2}(\%) \text {. }
$$

Alveolar partial pressure of $\mathrm{O}_{2}\left(\mathrm{P}_{\mathrm{A}} \mathrm{O}_{2} \mathrm{mmHg}\right)$ was expressed as:

$$
\mathrm{P}_{\mathrm{A}} \mathrm{O}_{2}=\left\{\left[\mathrm{FiO}_{2}(\%) / 100\right] \times\left(\mathrm{Patm}-\mathrm{PH}_{2} \mathrm{O}\right)\right\}-\left[\mathrm{PaCO}_{2}\right.
$$
$(\mathrm{mmHg}) / \mathrm{RQ}]$, 
where atmospheric pressure (Patm) at a sea level is $760 \mathrm{mmHg}, \mathrm{PH}_{2} \mathrm{O}$ is $47 \mathrm{mmHg}$, and RQ (respiratory quotient) is 0.8. Alveolar-arterial (A-a) gradient was calculated as:

A-a gradient $=\mathrm{P}_{\mathrm{A}} \mathrm{O}_{2}(\mathrm{mmHg})-\mathrm{PaO}_{2}(\mathrm{mmHg})$. Right-to-left pulmonary shunts $(\mathrm{Q} s / \mathrm{Qt})$ were calculated as described elsewhere (Vodoz et al. 2009).

\section{Counting of cells in the BAL fluid}

After sacrificing the animal, lungs and trachea were excised. The left lung was lavaged 3-times by saline $\left(0.9 \% \mathrm{NaCl}, 37^{\circ} \mathrm{C}\right.$, dose of $10 \mathrm{ml} / \mathrm{kg}$ b.w. $)$. Total number of cells in the BAL fluid was determined by an automated cell analyzer (Countess, Invitrogen, USA). Bronchoalveolar lavage (BAL) fluid was then centrifuged at $1500 \mathrm{rpm}$ for $15 \mathrm{~min}$. Differential count of cells in the BAL fluid sediment was evaluated microscopically after staining by May-Grünwald/Giemsa-Romanowski.

\section{Lung edema formation (wet/dry lung weight ratio)}

Strips of the right lung tissue were weighed, dried at $60{ }^{\circ} \mathrm{C}$ for $24 \mathrm{~h}$ and the wet/dry weight ratio was determined.

\section{Statistics}

GraphPad Prism (Version 6.01) software was used for statistical analyses. Statistical differences between the groups were determined by analysis of variance (ANOVA) with Bonferroni post hoc test or Kruskal-Wallis test. Results are presented as average with error bars indicating standard error of the mean (means \pm SEM).

\section{Results}

Body weights of animals and initial values of the parameters before induction of the ALI model were comparable between the groups (all $\mathrm{P}>0.05$ ).

\section{Respiratory parameters}

Lung lavage with saline induced an acute respiratory insufficiency characterized with decrease in lung compliance, increase in right-to-left pulmonary shunts with subsequent hypoxemia, hypercapnia and acidemia compared to non-lavaged controls (all $\mathrm{P}<0.001$, Tables 1 and 2). These changes have been reflected also by worsening in clinically relevant indexes of oxygenation (all $\mathrm{P}<0.001$, Table 2). As a result of insufficient gas exchange, ventilatory pressures (MAP and PIP) had to be elevated to higher values than in controls (Table 1). Roflumilast administration significantly improved $\mathrm{PaO}_{2}$ from $1 \mathrm{~h}(\mathrm{P}<0.01$, Table 2) and $\mathrm{PaCO}_{2}$ from $30 \mathrm{~min}(\mathrm{P}<0.05$, Table 1$)$, but had no positive effect on $\mathrm{pH}$ compared to ALI group $(\mathrm{P}>0.05$, Table 1). Roflumilast enhanced also other respiratory parameters compared to non-treated ALI group, i.e. MAP $(\mathrm{P}<0.001)$, PF ratio $(\mathrm{P}<0.05)$, and $\mathrm{P}_{\mathrm{A}} \mathrm{O}_{2}(\mathrm{P}<0.01)$ from 30 min of the therapy, AAG $(\mathrm{P}<0.05)$, VEI $(\mathrm{P}<0.05)$, and Cdyn $(\mathrm{P}<0.01)$ from $1 \mathrm{~h}$ of the therapy and OI $(\mathrm{P}<0.05)$ from $2 \mathrm{~h}$ of the therapy (Tables 1 and 2).

\section{Cells in the BAL fluid}

Repetitive lung lavage significantly elevated a total number of cells in the BAL fluid compared to controls ( $\mathrm{P}<0.001$ for ALI vs Control), while roflumilast inhibited the infiltration of cells into the lungs $(\mathrm{P}<0.01$ for ALI+Rofl vs ALI) (Fig. 1). As shown in Figure 2, induction of ALI model significantly increased the percentage of neutrophils $(\mathrm{P}<0.01$ for ALI vs Control) and decreased number of monocytes-macrophages ( $\mathrm{P}<0.01$ for ALI vs Control). Roflumilast therapy lowered number of neutrophils $(\mathrm{P}<0.001$ for $\mathrm{ALI}+\mathrm{Rofl}$ vs ALI) and elevated relative count of monocytes and macrophages $(\mathrm{P}<0.001$ for ALI+Rofl vs ALI).

\section{Lung edema formation}

Compared with controls, wet/dry weight ratio significantly increased in the ALI group $(\mathrm{P}<0.01)$. Roflumilast reduced lung wet/dry weight ratio vs ALI group $(\mathrm{P}<0.01)$ (Fig. 3)

\section{Discussion}

The neutrophil-mediated inflammation and lung edema formation are fundamental signs of ALI. We have assumed that administration of PDE4 inhibitor can alleviate these changes what can finally improve the lung functions of animals with model of ALI. Results of our study showed that intravenous delivery of $1 \mathrm{mg} / \mathrm{kg} \mathrm{b.w}$. of roflumilast reduced transmigration of cells, particularly of neutrophils into the lung, decreased generation of lung edema and enhanced gas exchange and other respiratory parameters in comparison with non-treated animals with ALI.

PDE4 inhibitors have previously demonstrated a number of anti-inflammatory actions including the inhibition of cell trafficking and microvascular leakage, release of cytokines and chemokines from inflammatory 
Table 1. Respiratory parameters before and after induction of ALI model (Before/After ALI) and after administration of the therapy (Th) in healthy ventilated and non-treated animals (Control group), in non-treated animals with ALI (ALI group) and in animals with ALI treated with roflumilast (ALI+Rofl group).

\begin{tabular}{|c|c|c|c|c|c|c|c|}
\hline & Before ALI & After ALI & $0.5 \mathrm{~h}$ Th & $1 \mathrm{~h}$ Th & $2 \mathrm{~h}$ Th & $3 \mathrm{~h}$ Th & $4 \mathrm{~h}$ Th \\
\hline \multicolumn{8}{|c|}{$\boldsymbol{M A P}(k P a)$} \\
\hline Control & $0.78 \pm 0.02$ & $0.79 \pm 0.01$ & $0.77 \pm 0.02$ & $0.76 \pm 0.02$ & $0.71 \pm 0.01$ & $0.74 \pm 0.02$ & $0.74 \pm 0.02$ \\
\hline$A L I$ & $0.80 \pm 0.02$ & $1.04 \pm 0.02^{\mathrm{a}}$ & $1.03 \pm 0.04^{\mathrm{a}}$ & $1.04 \pm 0.05^{\mathrm{a}}$ & $1.08 \pm 0.06^{\mathrm{a}}$ & $1.04 \pm 0.08^{\mathrm{a}}$ & $1.09 \pm 0.06^{\mathrm{a}}$ \\
\hline$A L I+R o f l$ & $0.80 \pm 0.02$ & $0.99 \pm 0.04$ & $0.90 \pm 0.04^{\mathrm{e}}$ & $0.90 \pm 0.05^{\mathrm{e}}$ & $0.90 \pm 0.04^{\mathrm{e}}$ & $0.85 \pm 0.02^{\mathrm{e}}$ & $0.91 \pm 0.06^{\mathrm{e}}$ \\
\hline \multicolumn{8}{|c|}{$\mathrm{PaCO}_{2}(k P a)$} \\
\hline Control & $4.22 \pm 0.17$ & $4.37 \pm 0.15$ & $4.30 \pm 0.14$ & $4.21 \pm 0.10$ & $3.89 \pm 0.29$ & $3.69 \pm 0.29$ & $3.85 \pm 0.08$ \\
\hline$A L I$ & $3.98 \pm 0.21$ & $6.18 \pm 0.14^{\mathrm{a}}$ & $6.43 \pm 0.23^{\mathrm{a}}$ & $6.65 \pm 0.34^{\mathrm{a}}$ & $6.57 \pm 0.26^{\mathrm{a}}$ & $6.19 \pm 0.22^{\mathrm{a}}$ & $6.01 \pm 0.38^{\mathrm{a}}$ \\
\hline$A L I+R o f l$ & $3.52 \pm 0.22$ & $6.04 \pm 0.26$ & $5.52 \pm 0.36^{\mathrm{c}}$ & $5.16 \pm 0.35^{b}$ & $4.94 \pm 0.29^{\mathrm{a}}$ & $4.73 \pm 0.32^{b}$ & $4.53 \pm 0.29^{b}$ \\
\hline \multicolumn{8}{|l|}{$p H$} \\
\hline Control & $7.55 \pm 0.01$ & $7.52 \pm 0.04$ & $7.43 \pm 0.02$ & $7.37 \pm 0.02$ & $7.32 \pm 0.02$ & $7.23 \pm 0.04$ & $7.22 \pm 0.03$ \\
\hline$A L I$ & $7.53 \pm 0.02$ & $7.18 \pm 0.02^{\mathrm{a}}$ & $7.19 \pm 0.03^{\mathrm{a}}$ & $7.19 \pm 0.03^{\mathrm{a}}$ & $7.13 \pm 0.04^{\mathrm{a}}$ & $7.06 \pm 0.04^{b}$ & $7.02 \pm 0.05^{\mathrm{a}}$ \\
\hline$A L I+R o f l$ & $7.58 \pm 0.03$ & $7.23 \pm 0.03$ & $7.23 \pm 0.03$ & $7.18 \pm 0.03$ & $7.08 \pm 0.03$ & $7.03 \pm 0.02$ & $7.03 \pm 0.03$ \\
\hline \multicolumn{8}{|l|}{ VEI } \\
\hline Control & $19.0 \pm 0.9$ & $18.2 \pm 0.6$ & $18.5 \pm 0.6$ & $18.9 \pm 0.4$ & $20.6 \pm 0.9$ & $22.6 \pm 2.6$ & $20.6 \pm 0.4$ \\
\hline$A L I$ & $20.5 \pm 1.1$ & $12.9 \pm 0.3^{\mathrm{b}}$ & $12.4 \pm 0.5^{\mathrm{b}}$ & $12.1 \pm 0.5^{\mathrm{a}}$ & $12.2 \pm 0.4^{\mathrm{a}}$ & $12.9 \pm 0.5^{\mathrm{a}}$ & $13.5 \pm 0.8^{\mathrm{a}}$ \\
\hline$A L I+R o f l$ & $23.3 \pm 1.5$ & $13.3 \pm 0.6$ & $14.9 \pm 1.1$ & $15.8 \pm 1.2^{\mathrm{f}}$ & $16.4 \pm 1.0^{\mathrm{e}}$ & $17.3 \pm 1.3^{\mathrm{e}}$ & $18.0 \pm 1.3^{\mathrm{e}}$ \\
\hline \multicolumn{8}{|c|}{ Cdyn $(\mathrm{ml} / \mathrm{kPa})$} \\
\hline Control & $14.5 \pm 0.5$ & $14.9 \pm 0.5$ & $15.1 \pm 0.5$ & $15.6 \pm 0.4$ & $15.3 \pm 0.4$ & $14.7 \pm 0.4$ & $15.3 \pm 0.5$ \\
\hline$A L I$ & $13.0 \pm 0.8$ & $7.2 \pm 0.9^{\mathrm{a}}$ & $7.7 \pm 0.4^{\mathrm{a}}$ & $6.2 \pm 0.9^{\mathrm{a}}$ & $6.4 \pm 0.9^{\mathrm{a}}$ & $4.4 \pm 1.2^{\mathrm{a}}$ & $5.1 \pm 1.0^{\mathrm{a}}$ \\
\hline$A L I+R o f l$ & $14.0 \pm 0.8$ & $7.8 \pm 0.6$ & $9.3 \pm 1.2$ & $9.7 \pm 1.2^{\mathrm{e}}$ & $10.0 \pm 1.3^{\mathrm{e}}$ & $10.0 \pm 1.2^{\mathrm{d}}$ & $9.3 \pm 1.2^{f}$ \\
\hline \multicolumn{8}{|l|}{$Q s / Q t(\%)$} \\
\hline Control & $3.8 \pm 0.6$ & $5.1 \pm 1.8$ & $3.7 \pm 0.8$ & $6.1 \pm 1.6$ & $5.8 \pm 0.4$ & $4.4 \pm 0.8$ & $1.3 \pm 0.5$ \\
\hline$A L I$ & $5.6 \pm 1.2$ & $23.8 \pm 0.5^{\mathrm{a}}$ & $24.2 \pm 0.6^{\mathrm{a}}$ & $25.0 \pm 0.3^{\mathrm{a}}$ & $25.0 \pm 0.3^{\mathrm{a}}$ & $25.0 \pm 0.2^{\mathrm{a}}$ & $24.8 \pm 0.3^{\mathrm{a}}$ \\
\hline$A L I+R o f l$ & $4.0 \pm 0.8$ & $23.0 \pm 1.1$ & $18.2 \pm 2.8$ & $16.6 \pm 3.5^{\mathrm{e}}$ & $15.8 \pm 3.4^{\mathrm{e}}$ & $16.6 \pm 4.0^{\mathrm{e}}$ & $13.4 \pm 3.6^{\mathrm{d}}$ \\
\hline
\end{tabular}

Abbreviations: MAP: mean airway pressure, $\mathrm{PaCO}_{2}$ : arterial partial pressure of carbon dioxide, $\mathrm{pH}$ : arterial $\mathrm{pH}$, VEI: ventilation efficiency index, Cdyn: dynamic lung compliance, Qs/Qt: intrapulmonary shunts. Statistical comparisons: for ALI vs Control: ${ }^{\text {a }} \mathrm{P}<0.001,{ }^{b} \mathrm{P}<0.01$, ${ }^{c} \mathrm{P}<0.05$; for ALI+Rofl vs ALI: ${ }^{\mathrm{d}} \mathrm{P}<0.001,{ }^{\mathrm{e}} \mathrm{P}<0.01,{ }^{\mathrm{f}} \mathrm{P}<0.05$. Data are expressed as means \pm SEM.

cells, production of reactive oxygen species (ROS), expression of cell adhesion molecules, attenuated bronchoconstriction etc. (Rabe 2010). These effects are attributed to maintained cAMP levels and enhanced protein kinase activity (PKA) (Bender and Beavo 2006). Roflumilast is a representant of the second generation of PDE4 inhibitors which was in 2010 approved to manage COPD (Field 2011). Roflumilast has shown to reduce a neutrophil infiltration, to decrease a release of inflammatory mediators, to inhibit a fibrotic remodeling, and to reduce an oxidative stress (Rabe 2010). In addition, although roflumilast is not known as a potent bronchodilator, modest improvements in $\mathrm{FEV}_{1}$ have been documented in clinical trials (Rabe et al. 2005, Garnock-Jones 2015). Nevertheless, majority of the information on roflumilast action is related to its oral administration. In our study, roflumilast was administered intravenously as this route of delivery is more suitable for anesthetized, tracheotomized and ventilated rabbits with model of ALI as well as for patients with ALI/ARDS.

In the present study, ALI model was induced by repetitive lung lavage with saline what removed a significant portion of pulmonary surfactant. This model of surfactant depletion is one of standardly used animal models of ALI which is usually elicited in rabbits (MatuteBello et al. 2008, Ronchi et al. 2012). Although this model does not provide such massive migration of cells and so convincing extent of inflammation as it was demonstrated for lipopolysaccharide (LPS)-induced models of ALI, disturbance of an alveolar-capillary lining early after the 
Table 2. Parameters expressing oxygenation before and after induction of ALI model (Before/After ALI) and after administration of the therapy (Th) in healthy ventilated and non-treated animals (Control group), in non-treated animals with ALI (ALI group) and in animals with ALI treated with roflumilast (ALI+Rofl group).

\begin{tabular}{|c|c|c|c|c|c|c|c|}
\hline & Before ALI & After ALI & $0.5 \mathrm{~h} T h$ & $1 \mathrm{~h} \mathrm{Th}$ & $2 \mathrm{~h}$ Th & $3 \mathrm{~h} \mathrm{Th}$ & $4 \mathrm{~h} \mathrm{Th}$ \\
\hline \multicolumn{8}{|l|}{$\mathrm{PaO}_{2}$} \\
\hline Control & $81.04 \pm 1.29$ & $78.69 \pm 3.56$ & $81.52 \pm 1.59$ & $76.94 \pm 4.22$ & $77.24 \pm 4.05$ & $81.9 \pm 1.72$ & $87.83 \pm 1.54$ \\
\hline$A L I$ & $78.21 \pm 3.18$ & $16.71 \pm 1.88^{\mathrm{a}}$ & $21.09 \pm 4.33^{\mathrm{a}}$ & $17.34 \pm 5.19^{\mathrm{a}}$ & $12.32 \pm 1.52^{\mathrm{a}}$ & $12.88 \pm 0.99^{\mathrm{a}}$ & $18.62 \pm 5.08^{\mathrm{a}}$ \\
\hline$A L I+R o f l$ & $79.74 \pm 2.05$ & $20.34 \pm 4.09$ & $39.29 \pm 10.12$ & $45.37 \pm 12.00^{\mathrm{e}}$ & $48.44 \pm 11.62^{\mathrm{d}}$ & $51.79 \pm 13.62^{\mathrm{d}}$ & $56.76 \pm 11.03^{\mathrm{d}}$ \\
\hline \multicolumn{8}{|l|}{$O I$} \\
\hline Control & $1.00 \pm 0.02$ & $0.99 \pm 0.03$ & $0.93 \pm 0.03$ & $0.95 \pm 0.03$ & $0.89 \pm 0.02$ & $0.92 \pm 0.02$ & $0.85 \pm 0.03$ \\
\hline$A L I$ & $1.05 \pm 0.07$ & $7.57 \pm 1.04^{\mathrm{a}}$ & $7.98 \pm 1.22^{\mathrm{a}}$ & $9.02 \pm 2.14^{\mathrm{a}}$ & $9.09 \pm 2.03^{\mathrm{a}}$ & $9.36 \pm 2.4^{\mathrm{a}}$ & $7.57 \pm 1.43^{\mathrm{a}}$ \\
\hline$A L I+R o f l$ & $1.06 \pm 0.04$ & $7.71 \pm 0.93$ & $5.99 \pm 1.76$ & $5.73 \pm 1.77$ & $4.56 \pm 1.38^{\mathrm{f}}$ & $3.82 \pm 1.61^{\mathrm{f}}$ & $2.27 \pm 0.73^{\mathrm{e}}$ \\
\hline \multicolumn{8}{|l|}{ PF ratio } \\
\hline Control & $602.3 \pm 9.0$ & $590.2 \pm 26.7$ & $611.5 \pm 11.9$ & $577.0 \pm 31.7$ & $579.3 \pm 30.4$ & $614.2 \pm 12.9$ & $659.7 \pm 11.7$ \\
\hline$A L I$ & $591.1 \pm 25.9$ & $104.8 \pm 11.3^{\mathrm{a}}$ & $102.4 \pm 10.8^{\mathrm{a}}$ & $84.2 \pm 8.2^{\mathrm{a}}$ & $92.0 \pm 13.2^{\mathrm{a}}$ & $98.3 \pm 8.3^{\mathrm{a}}$ & $105.6 \pm 11.7^{\mathrm{a}}$ \\
\hline$A L I+R o f l$ & $595.1 \pm 16.5$ & $140.2 \pm 20.3$ & $269.0 \pm 82.4^{\mathrm{f}}$ & $340.9 \pm 90.1^{\mathrm{e}}$ & $364.0 \pm 87.3^{\mathrm{d}}$ & $389.5 \pm 102.7^{\mathrm{d}}$ & $426.6 \pm 83.2^{\mathrm{d}}$ \\
\hline \multicolumn{8}{|l|}{$\boldsymbol{P}_{A} \boldsymbol{O}_{2}$} \\
\hline Control & $673.4 \pm 1.6$ & $672.0 \pm 1.4$ & $672.7 \pm 1.3$ & $673.6 \pm 0.9$ & $676.6 \pm 1.5$ & $678.4 \pm 2.7$ & $676.9 \pm 0.8$ \\
\hline$A L I$ & $675.7 \pm 1.9$ & $652.2 \pm 2.1^{\mathrm{a}}$ & $648.5 \pm 3.9^{\mathrm{a}}$ & $650.7 \pm 3.2^{\mathrm{a}}$ & $651.4 \pm 2.4^{\mathrm{a}}$ & $655.0 \pm 2.1^{\mathrm{a}}$ & $656.6 \pm 3.6^{\mathrm{a}}$ \\
\hline$A L I+R o f l$ & $680.0 \pm 2.0$ & $655.7 \pm 2.7$ & $661.3 \pm 3.4^{\mathrm{e}}$ & $663.3 \pm 3.1^{\mathrm{e}}$ & $664.9 \pm 3.0^{\mathrm{e}}$ & $667.9 \pm 2.7^{\mathrm{e}}$ & $666.6 \pm 4.9^{\mathrm{f}}$ \\
\hline \multicolumn{8}{|l|}{$A A G$} \\
\hline Control & $612.0 \pm 11.7$ & $593.9 \pm 33.6$ & $606.6 \pm 14.7$ & $561.9 \pm 41.1$ & $563.3 \pm 38.0$ & $601.9 \pm 13.5$ & $663.2 \pm 14.6$ \\
\hline$A L I$ & $586.6 \pm 23.3$ & $110.8 \pm 11.6^{\mathrm{a}}$ & $150.9 \pm 38.7^{\mathrm{a}}$ & $136.6 \pm 45.3^{\mathrm{a}}$ & $147.5 \pm 56.1^{\mathrm{a}}$ & $157.6 \pm 62.3^{\mathrm{a}}$ & $164.4 \pm 62.4^{\mathrm{a}}$ \\
\hline$A L I+R o f l$ & $597.6 \pm 16.8$ & $138.8 \pm 17.0$ & $269.9 \pm 71.4$ & $306.4 \pm 85.0^{\mathrm{f}}$ & $328.6 \pm 83.1^{\mathrm{f}}$ & $347.9 \pm 95.4^{\mathrm{f}}$ & $385.5 \pm 82.2^{\mathrm{e}}$ \\
\hline
\end{tabular}

Abbreviations: $\mathrm{PaO}_{2}$ : arterial partial pressure of oxygen, $\mathrm{OI}$ : oxygenation index, $\mathrm{PF}$ ratio: $\mathrm{PaO}_{2} / \mathrm{FiO}_{2}, \mathrm{P}_{\mathrm{A}} \mathrm{O}_{2}$ : alveolar partial pressure of oxygen, AAG: alveolar-arterial gradient of oxygen. Statistical comparisons: for ALI vs Control: ${ }^{a} P<0.001,{ }^{b} P<0.01,{ }^{c} P<0.05$; for ALI+Rofl vs ALI: ${ }^{\mathbf{d}} \mathrm{P}<0.001,{ }^{\mathrm{e}} \mathrm{P}<0.01,{ }^{\mathrm{f}} \mathrm{P}<0.05$. Data are expressed as means $\pm \mathrm{SEM}$.

lung lavages caused a significant recruitment of inflammatory cells, particularly of neutrophils, into the lung. Activated neutrophils and alveolar macrophages induce an injury of epithelial and endothelial cells, enhance an apoptosis of epithelial cells, cause a degradation of surfactant proteins, stimulate a generation of ROS in the lung what results in a destruction of the basement membrane, alteration of alveolar-capillary permeability and final deterioration of oxygenation (Ware 2006, Grommes and Soehnlein 2011). In addition, migrating groups of neutrophils mechanically damage the alveoli and worsen an accumulation of fluid in the alveolar space (Kobr et al. 2010). In our study, roflumilast treatment reduced a severity of the lavage-induced lung injury, in part by diminishing the infiltration of neutrophils into the lung. Inhibited accumulation of neutrophils in the lung after treatment with PDE4 inhibitors were presented also in a model of LPS-induced lung injury (Kubo et al. 2012), in the airway disease models (Bundschuh et al. 2001) as well as in rats with a saline-lavage induced model of ALI (Häfner and Germann 2000).

Repetitive lavage by saline used for induction of ALI model in this study triggered a generation of lung edema. Pulmonary edema is one of typical pathophysiological features of ALI/ARDS which can be clearly distinguished from cardiogenic pulmonary edema (Zemans and Matthay 2004, Schmickl et al. 2015). The pulmonary edema in ALI originates from altered permeability of the alveolar epithelial and/or capillary barriers. Although epithelial barriers are tighter than endothelial, these two have functional interactions (Matthay et al. 2012). The endothelial barrier is sealed by tight and adherens junctions, both of which are targeted during acute inflammation what results in the formation of intercellular gaps with consecutive extravasation of the proteinaceous fluid (Vandenbroucke et al. 2008, Spindler et al. 2010). Treatment with intravenous roflumilast in our study effectively attenuated the formation of lung 


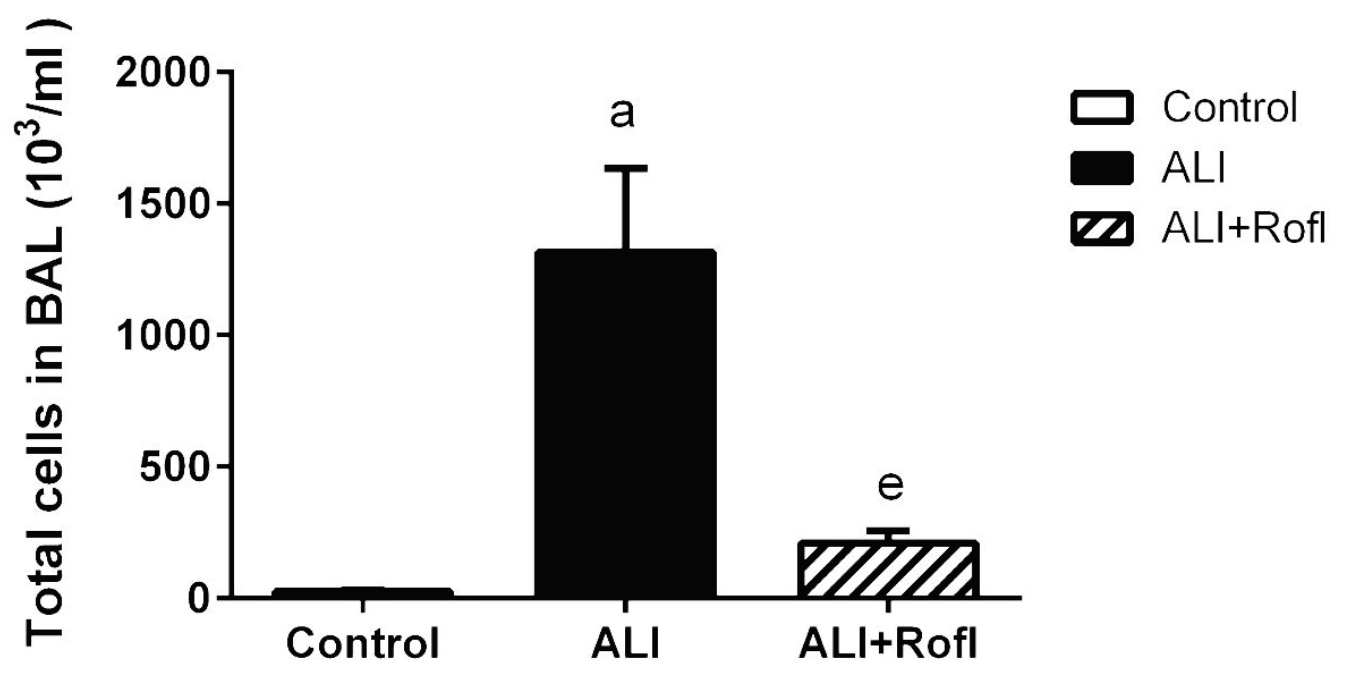

Fig. 1. Total count of cells in the BAL fluid at the end of experiment after systemic therapy of roflumilast (ALI+Rofl) in rabbit model. Statistical comparisons: for ALI vs Control: ${ }^{\text {a }} \mathrm{P}<0.001$; for ALI+Rofl vs ALI: ${ }^{\text {e }} \mathrm{P}<0.01$.

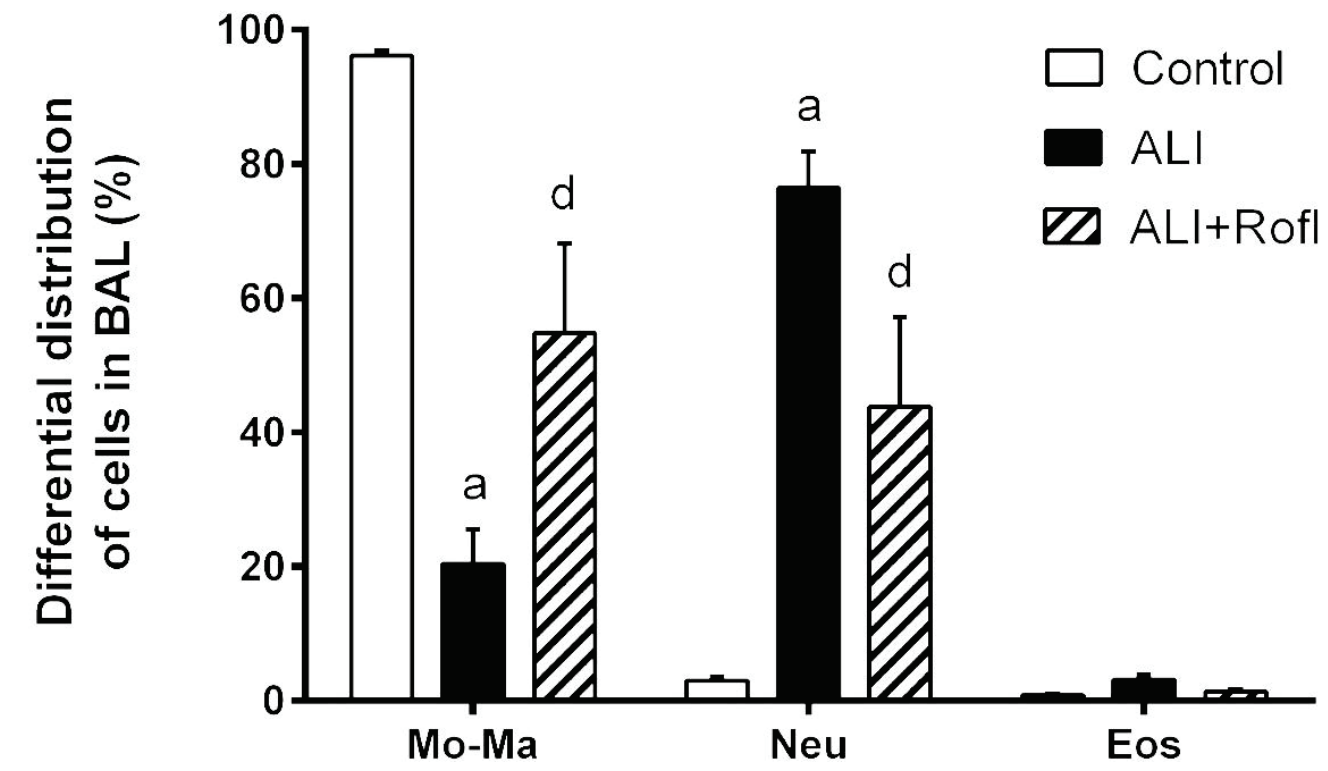

Fig. 2. Differential count (percentage) of cells in the BAL fluid at the end of experiment. Abbreviations: Mo-Ma: monocytesmacrophages, Neu: neutrophils, Eos: eosinophils. Statistical comparisons: for ALI vs Control: ${ }^{a} P<0.001$; for ALI+Rofl vs ALI: ${ }^{d} P<0.001$.

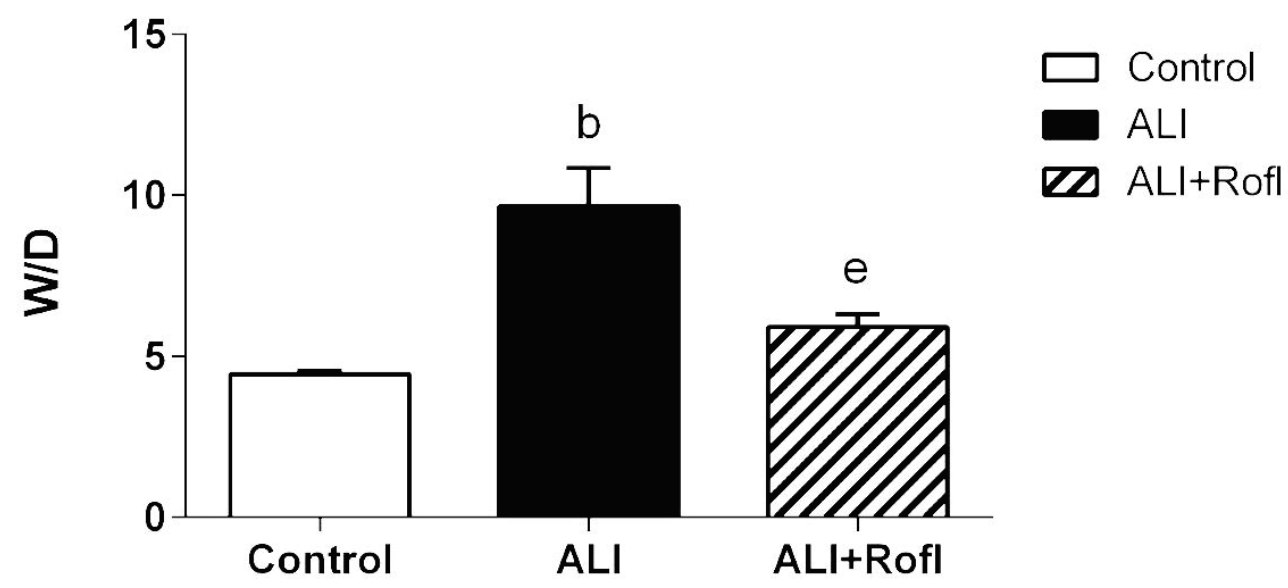

Fig. 3. Wet/dry weight ratio of the rabbits. The lobe of the right lung was excised after systemic therapy of roflumilast in rabbit model. Statistical comparisons: for ALI vs Control: ${ }^{b} \mathrm{P}<0.01$; for ALI+Rofl vs ALI: ${ }^{\mathrm{e}} \mathrm{P}<0.01$. 
edema expressed by wet-dry lung weight ratio. We can presume that roflumilast alleviated a lavage-induced breakdown of the endothelial barrier what was associated with reduced fluid loss and increased microcirculatory flow. Roflumilast is known to inhibit microvascular leakage and edema formation (Bundschuh et al. 2001), likely via cAMP regulation of the stability of intercellular junctions by PKA- or EPAC/Rap1-dependent activation of small GTPase Rac1 (Adamson et al. 1998, Birukova et al. 2008, Spindler et al. 2010). Increased cAMP levels effectively stabilize the endothelial barriers under resting conditions and in acute inflammation (Birukova et al. 2008, Spindler et al. 2010). Consistently, increased cAMP levels in the endothelial cells prevented increased endothelial permeability by inflammatory mediators in vitro and in single postcapillary venules in vivo (Adamson et al. 2003, Schlegel and Waschke 2009, Beckers et al. 2010). PDE4 inhibitors reduced the vascular leakage and deposition of alveolar fibrin or production of hyaline membranes resulting from plasma protein leakage also in a rat model of neonatal lung injury (de Visser et al. 2008) and in rats with saline lavage-induced model of ALI (Häfner and Germann 2000). The use of agents increasing cAMP decreased the formation of pulmonary edema in the isolated lungs of models with lung injury (Schmidt et al. 2008, Witzenrath et al. 2009), as well.

The above mentioned transmigration and activation of inflammatory cells and lung edema formation in our study resulted in a worsening of the respiratory parameters. Early after the lung lavages, the oxygenation and efficacy of ventilation decreased and these changes were relatively stable during the whole experiment in the ALI model group. Similar findings were previously presented by other researchers (Ronchi et al. 2012, Kamiyama et al. 2014). Administration of roflumilast led to significant improvement of blood gases as well as of measured respiratory parameters and calculated indexes compared to non-treated animals with ALI, whereas the changes become significant within $2 \mathrm{~h}$ after roflumilast delivery. We presume that the rapid improvement in oxygenation is related to a decrease in the right-to-left pulmonary shunts. Our results are in accordance with findings that PDE4 is present also in the pulmonary artery smooth muscle cells and that exposure to hypoxia increases expression of several PDE4 isoforms (Millen et al. 2006). From this reason, PDE4 inhibitors have been considered for perspective treatments of neonatal pulmonary hypertension (Farrow and Steinhorn 2011).

Concluding, intravenous administration of roflumilast reduced PMN migration into the lung, decreased lung edema formation and improved respiratory parameters in rabbits with repetitive saline lung lavage-induced ALI. These results indicate that PDE4 inhibitors could be of benefit also in the treatment of ALI/ARDS in patients. However, further extensive testing in the laboratory and clinical conditions is needed before this treatment can be recommended.

\section{Conflict of Interest}

There is no conflict of interest.

\section{Acknowledgements}

This work was supported by project "Center of Experimental and Clinical Respirology“, ITMS code: 26220120004; and by projects APVV-15-0075, and VEGA 1/0305/14.

\section{References}

ADAMSON RH, LIU B, FRY GN, RUBIN LL, CURRY FE: Microvascular permeability and number of tight junctions are modulated by cAMP. Am J Physiol Heart Circ Physiol 274: H1885-H1894, 1998.

ADAMSON RH, ZENG M, ADAMSON GN, LENZ JF, CURRY FE: PAF- and bradykinin-induced hyperpermeability of rat venules is independent of actin-myosin contraction. Am J Physiol Heart Circ Physiol 285: H406-H417, 2003.

BECKERS CM, VAN HINSBERGH VW, VAN NIEUW AMERONGEN GP: Driving Rho GTPase activity in endothelial cells regulates barrier integrity: Thromb Haemost 103: 40-55, 2010.

BENDER AT, BEAVO JA: Cyclic nucleotide phosphodiesterases: molecular regulation to clinical use. Pharmacol Rev 58: 488-520, 2006.

BIRUKOVA AA, ZAGRANICHNAYA T, ALEKSEEVA E, BOKOCH GM, BIRUKOV KG: Epac/Rap and PKA are novel mechanisms of ANP-induced Rac-mediated pulmonary endothelial barrier protection. $J$ Cell Physiol 215: 715-724, 2008. 
BUNDSCHUH DS, ELTZE M, BARSIG J, WOLLIN L, HATZELMANN A, BEUME R: In vivo efficacy in airway disease models of roflumilast, a novel orally active PDE4 inhibitor. J Pharmacol Exp Ther 297: 280-290, 2001.

DE VISSER YP, WALTHER FJ, LAGHMANI EH, VAN WIJNGAARDEN S, NIEUWLAND K, WAGENAAR GT: Phosphodiesterase-4 inhibition attenuates pulmonary inflammation in neonatal lung injury. Eur Respir J 31: 633-644, 2008.

FARROW KN, STEINHORN RH: Phosphodiesterases: emerging therapeutic targets for neonatal pulmonary hypertension. Handb Exp Pharmacol 204: 251-277, 2011.

FIELD SK: Roflumilast, a novel phosphodiesterase 4 inhibitor, for COPD patients with a history of exacerbations. Clin Med Insights Circ Respir Pulm Med 5: 57-70, 2011.

GARNOCK-JONES KP: Roflumilast: a review in COPD. Drugs 75: 1645-1656, 2015.

GROMMES J, SOEHNLEIN O: Contribution of neutrophils to acute lung injury. Mol Med 17: 293-307, 2011.

HÄFNER D, GERMANN PG: Additive effects of phosphodiesterase-4 inhibition on effects of rSP-C surfactant. $A m$ J Respir Crit Care Med 161: 1495-1500, 2000.

HOUSLAY MD, SCHAFER P, ZHANG KY: Keynote review: phosphodiesterase-4 as a therapeutic target. Drug Discov Today 10: 1503-1519, 2005.

KAMIYAMA J, JESMIN S, SAKURAMOTO H, SHIMOJO N, ISLAM MM, KHATUN T, OKI M, KAWANO S, MIZUTANI T: Assessment of circulatory and pulmonary endothelin-1 levels in a lavage-induced surfactantdepleted lung injury rabbit model with repeated open endotracheal suctioning and hyperinflation. Life Sci 118: 370-378, 2014.

KOBR J, KUNTSCHER V, MOLACEK J, HES O, PIZINGEROVA K, KOCOVA J, TOPOLCAN O: Diffuse alveolar damage due to inappropriate strategy of mechanical ventilation in an experimental porcine model. In Vivo 24 : 699-704, 2010.

KUBO S, KOBAYASHI M, IWATA M, MIYATA K, TAKAHASHI K, SHIMIZU Y: Anti-neutrophilic inflammatory activity of ASP3258, a novel phosphodiesterase type 4 inhibitor. Int Immunopharmacol 12: 59-63, 2012.

MATTHAY MA, WARE LB, ZIMMERMAN GA: The acute respiratory distress syndrome. J Clin Invest 122: 2731-2740, 2012.

MATUTE-BELLO G, FREVERT CW, MARTIN TR: Animal models of acute lung injury. Am J Physiol Lung Cell Mol Physiol 295: L379-L399, 2008.

MAURICE DH, KE H, AHMAD F, WANG Y, CHUNG J, MANGANIELLO VC: Advances in targeting cyclic nucleotide phosphodiesterases. Nat Rev Drug Discov 13: 290-314, 2014.

MILLEN J, MACLEAN MR, HOUSLAY MD: Hypoxia-induced remodelling of PDE4 isoform expression and cAMP handling in human pulmonary artery smooth muscle cells. Eur J Cell Biol 85: 679-691, 2006.

PARIKH N, CHAKRABORTI AK: Phosphodiesterase 4 (PDE4) Inhibitors in the treatment of COPD: promising drug candidates and future directions. Curr Med Chem 23: 129-141, 2016.

RABE KF, BATEMAN ED, O’DONNELL D, WITTE S, BREDENBROKER D, BETHKE TD: Roflumilast-an oral antiinflammatory treatment for chronic obstructive pulmonary disease: a randomised controlled trial. Lancet 366: 563-571, 2005.

RABE KF: Roflumilast for the treatment of chronic obstructive pulmonary disease. Expert Rev Respir Med 4: 543-555, 2010.

RONCHI CF, FIORETTO JR, FERREIRA AL, BERCHIERI-RONCHI CB, CORREA CR, KUROKAWA CS, CARPI MF, MORAES MA, YEUM KJ: Biomarkers for oxidative stress in acute lung injury induced in rabbits submitted to different strategies of mechanical ventilation. J Appl Physiol 112: 1184-1190, 2012.

SCHLEGEL N, WASCHKE J: Impaired cAMP and Rac 1 signaling contribute to TNF- $\alpha$-induced endothelial barrier breakdown in microvascular endothelium. Microcirculation 16: 521-533, 2009.

SCHMICKL CN, BIEHL M, WILSON GA, GAJIC O: Comparison of hospital mortality and long-term survival in patients with acute lung injury/ARDS vs cardiogenic pulmonary edema. Chest 147: 618-625, 2015.

SCHMIDT EP, DAMARLA M, RENTSENDORJ O, SERVINSKY LE, ZHU B, MOLDOBAEVA A, GONZALEZ A, HASSOUN PM, PEARSE DB: Soluble guanylyl cyclase contributes to ventilator-induced lung injury in mice. Am J Physiol Lung Cell Mol Physiol 295: L1056-L1065, 2008. 
SPINDLER V, SCHLEGEL N, WASCHKE J: Role of GTPases in control of microvascular permeability. Cardiovasc Res 87: 243-253, 2010.

VANDENBROUCKE E, MEHTA D, MINSHALL R, MALIK AB: Regulation of endothelial junctional permeability. Ann N Y Acad Sci 1123: 134-145, 2008.

VODOZ JF, COTTIN V, GLÉRANT JC, DERUMEAUX G, KHOUATRA C, BLANCHET AS, MASTROÏANNI B, BAYLE JY, MORNEX JF, CORDIER JF: Right-to-left shunt with hypoxemia in pulmonary hypertension. BMC Cardiovasc Disord 9: 15, 2009.

WARE LB: Pathophysiology of acute lung injury and the acute respiratory distress syndrome. Semin Respir Crit Care Med 27: 337-349, 2006.

WITZENRATH M, GUTBIER B, SCHMECK B, TENOR H, SEYBOLD J, KUELZER R, GRENTZMANN G, HATZELMANN A, VAN LAAK V, TSCHERNIG T, MITCHELL TJ, SCHUDT C, ROSSEAU S, SUTTORP N, SCHUTTE H: Phosphodiesterase 2 inhibition diminished acute lung injury in murine pneumococcal pneumonia. Crit Care Med 37: 584-590, 2009.

ZEMANS RL, MATTHAY MA: Bench-to-bedside review: the role of the alveolar epithelium in the resolution of pulmonary edema in acute lung injury. Crit Care 8: 469-477, 2004.

ZHU J, PAUL WE: CD4 T cells: fates, functions, and faults. Blood 112: 1557-1569, 2008. 